\title{
ANALISA IMPLEMENTASI UU ITE PASAL 28 AYAT 2 DALAM MENGURANGI UJARAN KEBENCIAN DI MEDIA SOSIAL
}

\author{
Roida Pakpahan \\ Program Studi Sistem Informasi \\ Fakultas Teknologi Informasi \\ Universitas Bina Sarana Informatika \\ roida.rkh@bsi.ac.id
}

Received: May 12, 2021. Revised: May 18, 2021. Accepted: June 02, 2021.

Published: June 20, 2021. Issue Period: Vol.5 No.1 (2021), Pp.111-119

\begin{abstract}
Abstrak: Kebaradaan media sosial saat ini sudah menjadi bagian dari trend gaya hidup masyarakat Indonesia hal ini terlihat dari semakin tingginya pengguna media sosial di Indonesia yang hingga kini telah mencapai 170 juta pengguna, media sosial bagi sebagian orang digunakan untuk wadah pertemanan, sebagai ruang untuk membuktikan eksistensi diri dan media untuk mendulang rupiah melalui konten-konten yang kreatif sperti yang dilakukan seorang youtuber. Namun disisi lain media sosial juga digunakan oleh sebagian penggunanya atau yang sering disebut dengan istilah netizen untuk hal-hal yang bermuatan negatif dengan memberikan komentar, status, foto, video dan lainnya yang berisi ujaran kebencian. Maraknya ujaran kebencian dimedia sosial memberikan dampak negatif karna menimbulkan kegaduhan dimedia sosial yang dapat menimbulkan konflik internal maupun konflik sosial. Adanya UU ITE Pasal 28 ayat 2 diharapkan dapat meminimalisasi atau mengurangi ujaran kebencian dimedia sosial terlebih dengan adanya wacana dari pemerintah untuk merevisi UU ITE 2008 diharapkan mampu menciptakan undang-undang yang lebih baik lagi, sehinga pengguna media sosial dapat menjadikan media sosial sebagai media yang sehat dan produktif, ruang digital yang menyenangkan bagi penggunanya. Dan dengan kehadiran Virtual Police diharapkan dimasa depan media sosial dapat digunakan secara beretika dan dimanfaatkan untuk kebaikan hidup untuk membaikkan kehidupan dengan menggunakannya secara cerdas dan bijaksana.
\end{abstract}

\section{Kata kunci: Netizen, UU ITE, Virtual Police, Kebaikan}

Abstract: The existence of social media has now become part of the lifestyle trend of the Indonesian people, this can be seen from the increasing number of social media users in Indonesia, which until now has reached 170 million users, social media for some people is used as a forum for friendship, as a space to prove their existence. and media to gain rupiah through creative content like what a YouTuber does. But on the other hand, social media is also used by some users or what is often referred to as netizens for things that

DOI: $10.52362 /$ jisicom.v5i1.465

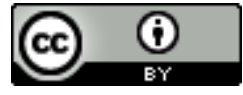

Ciptaan disebarluaskan di bawah Lisensi Creative Commons Atribusi 4.0 Internasional. 
have negative content by providing comments, status, photos, videos and others that contain hate speech. The rise of hate speech in social media has a negative impact because it creates a commotion in social media which can lead to internal conflict as well as social conflict. The existence of the ITE Law Article 28 paragraph 2 is expected to minimize or reduce hate speech in social media, especially with the discourse from the government to revise the 2008 ITE Law, which is expected to be able to create even better laws, so that social media users can make social media a healthy media. and productive, fun digital space for its users. And with the presence of Virtual Police, it is hoped that in the future social media can be used ethically and used for the good of life to improve life by using it intelligently and wisely.

\section{Keywords: Netizens, UU ITE, Virtual Police, Kindness}

\section{PENDAHULUAN}

Maraknya ujaran kebencian yang terjadi dimedia sosial menjadi hal menarik untuk diteliti, terlebih saat ini media sosial menjadi bagian dari trend gaya hidup masyrakat Indonesia hal ini terlihat dari laporan yang dirilis We Are social \& Hootsuite pada bulan Januari 2021 yang menyatakan jumlah pengguna aktif media sosial (medsos) di Indonesia hingga saat ini telah mencapai 170 juta pengguna dan rata-rata dari mereka menghabiskan waktu 3 jam 14 menit di platform jejaring sosial, lebih lanjut dalam laporan tersebut dinyatakan, pengguna aktif media sosial di Indonesia mengalami penambahan yang signifikan yaitu bertambah 6,3\% atau setara 10 juta pengguna dibandingkan pada Januari 2020. Dan media sosial yang paling banyak digunakan adalah YouTube, WhatsApp, Instagram, Facebook dan Twitter, 2021 (tekno.kompas.com) [1]

Meskipun pada awalnya keberadaan media sosial digunakan untuk memperpanjang silah turahmi dan media untuk berbagi hal-hal positif namun belakangan ini banyak pengguna media sosial atau yang sering disebut netizen yang menggunakan media sosial untuk hal-hal yang negatif diantaranya menggunakan media sosial untuk mengungangkapkan rasa kebencian atau menyebar kebencian baik lewat komentar-komentar negatif maupun melalui konten-konten yang berisi ujuran kebencian (hate speech) yang memberikan dampak negatif pada pengguna media sosial lainnya yang dapat memicu kegaduhan dimasyrakat sehingga menimbulkan konflik internal maupun konflik sosial.

Penelitian yang dilakukan oleh Okky dan Budi (2020) [2] dengan memanfaatkan Artificial Intelligence (AI) untuk mendeteksi ujaran kebencian dan bahasa kasar yang di-cuit-kan oleh netizen Indonesia pada media sosial Twitter, menyatakan dari total 13.169 cuitan yang berhasil dikumpulkan dengan memanfaatkan Twitter Search API, tercatat sebanyak 5.561 cuitan merupakan ujaran kebencian. Dan menurut Okky, ujaran kebencian tersebut dikategorikan menjadi lima kategori, seperti: agama, ras, fisik, gender atau orientasi seksual, dan umpatan lainnya.

Disisi lain keberadaan UU ITE Tahun 2008 pasal 28 ayat 2 yang menjadi salah satu undang-undang yang digunakan dalam aturan penggunaan media sosial di Indonesia masih menjadi undang-undang yang kontroversial dalam artian ada sebahagian masyarakat Indonesia yang mendukung adanya pasal tersebut namun disisi lain ada sebagian masyrakat yang berharap undang - undang tersebut segra dihapuskan dengan alasan undang-undang tersebut mengekang kebebasan berekspresi meskipun pada hakekatnya kebebasan berpendapat harusnya diimbangi dengan kecerdasan dalam bertutur kata sehingga tidak menyinggung atau melukai perasaan orang lain dalam menggunakan media sosial sehingga tidak terjerat pada kasus hukum pidana UU ITE Pasal 28 ayat 2. Di media sosial kita bisa bebas berpendapat dan berekspresi, namun perlu ditegaskan bahwa kebebasan tersebut bukanlah kebebasan mutlak tanpabatas dan etika, Bersosmed (2017) [3]

DOI: $10.52362 /$ jisicom.v5i1.465

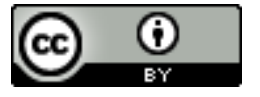

Ciptaan disebarluaskan di bawah Lisensi Creative Commons Atribusi 4.0 Internasional. 
Adapun tujuan dari penelitian ini adalah untuk melihat sejauh mana keberadaan UU ITE Pasal 28 ayat 2 dapat mengurangi ujaran kebencian di media sosial sehingga pengguna media sosial di Indonesia menggunakan media sosial secara cerdas dan bijaksana.

\section{KAJIAN TEORI}

\section{A. Media Sosial}

Media sosial merupakan platform media yang memfokuskan pada eksistensi pengguna yang memfasilitasi mereka dalam beraktifitas maupun berkolaborasi. Karena itu media sosial dapat dilihat sebagai medium (fasilitator) online yang menguatkan hubungan antar pengguna sekaligus sebuah ikatan sosial, Dijk dalam Nasrullah (2015) [4]. Selanjutnya menurut Meike dan Young dalam Nasrullah (2015) [4] menyatakan media sosial merupakan konvergensi antara komunikasi personal dalam arti saling berbagi diantara individu (to be share one-to-one) dan media publik untuk berbagi kepada siapa saja tanpa ada kekhususan individu.

Menurut Boyd dalam Nasrullah (2015) [4] media sosial adalah kumpulan perangkat lunak yang memungkinkan individu maupunkomunitas untuk berkumpul, berbagi, berkomunikasi, dan dalam kasus tertentu salingberkolaborasi atau bermain. Media sosial memiliki kekuatan pada user-generated content (UGC) dimana konten dihasilkan oleh pengguna, bukan oleh editor sebagaimana di instansi media massa. Lebih lanjut Puntoadi (2011)[5], menyatakan Media sosial diawali dari tiga hal, yaitu Sharing, Collaborating dan Connecting.

Ada enam kategori besar untuk melihat pembagian media sosial, menurut Nasullah (2015) [4] yaitu:

1. Media Jejaring Sosial (Social networking)

Media jejaring sosial merupakan medium yang paling popular. Media ini merupakansarana yang bisa digunakan pengguna unutk melakukan hubungan sosial, termasuk konsekuensi atau efek dari hubungan sosial tersebut di dunia virtual. Karakter utama dari situs jejaring sosial adalah setiap pengguna membentuk jaringan pertemanan, baik terhadappengguna yang sudah diketahuinya dan kemungkinan saling bertemu di dunianyata (offline) maupun membentuk jaringan pertemanan baru. Jejaring sosial yang paling banyak digunakan diantranya facebook dan Linked In.

2. Jurnal online (blog)

Blog merupakan media sosial yang memungkinkan penggunanya untuk mengunggah aktifitas keseharian, saling mengomentari dan berbagi, baik tautan web lain, informasi dan sebagainya. Pada awalnya blog merupakan suatu bentuk situs pribadi yang berisi kumpulan tautan ke situs lain yang dianggap menarik dan diperbarui setiap harinya. Pada perkembangan selanjutnya, blog banyak jurnal (tulisan keseharian pribadi) pemilik media dan terdapat kolom komentar yang bisa diisi oleh pengguna. Secara mekanis, jenis media sosial ini bisa dibagi menjadi dua, yaitu kategori personal homepage, yaitu pemilik menggunakan nama domain sendiri seperti .com atau.net dan yang kedua dengan menggunakan failitas penyedia halaman weblog gratis, seperti wordpress atau blogspot.

3. Jurnal online sederhana atau microblog (micro-blogging)

Microblogging merupakan jenis media sosial yang memfasilitasi pengguna untuk menulis dan mempublikasikan aktifitas serta atau pendapatnya. Contoh microblogging yang paling banyak digunakan adalah Twitter.

4. Media berbagi (media sharing)

Situs berbagi media merupakan jenis media sosial yang memfasilitasi penggunanya untuk berbagi media, mulai dari dokumen (file), video, audio, gambar, dan sebagainya. Contoh media ini adalah: Youtube, Flickr, Photobucket, atau snapfish.

5. Penanda sosial (social bookmarking)

Penanda sosial merupakan media sosialyang bekerja untuk mengorganisasi, menyimpan, mengelola dan mencari informasi atau berita tertentu secara online. Beberapa situs sosial bookmarking yangpopular adalah

DOI: $10.52362 /$ jisicom.v5i1.465

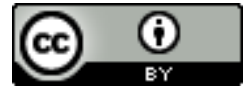

Ciptaan disebarluaskan di bawah Lisensi Creative Commons Atribusi 4.0 Internasional. 
delicious.com,stumbleUpon.com, Digg.com, Reddit.com,dan untuk di Indonesia ada LintasMe.

6. Media konten bersama atau wiki.

Media sosial ini merupakan situs yang kontennya hasil kolaborasi dari para penggunanya. Mirip dengan kamus atau ensiklopedi, wiki menghadirkan kepada pengguna pengertian, sejarah hingga rujukan buku atau tautan tentang satu kata. Dalam prakteknya, penjelasan-penjelasan tersebut dikerjakan oleh pengunjung, artinya ada kolaborasi atau kerja sama darisemua pengunjung untuk mengisi konten dalam situs ini.

Beberapa manfaat media sosial menurut (Puntoadi, 2011) [5] yang memberi manfaat yang sangat penting, diantaranya:

1. Personal branding is not only figure, it's for everyone. Berbagai media sosial seperti facebook,twitter, YouTube dapat menjadi media untuk orang berkomunikasi, berdiskusi, bahkan mendapatkan popularitas di sosial media.

2. Fantastic marketing result throught social media. People don't watch TV's anymore, they watch their mobile phones. Fenomena dimana cara hidup masyarakat saat ini cenderung lebih memanfaatkan telepon genggam mereka yang sudah terkenal dengan sebutan "smartphones". Dengan smartphone, kita dapat melihat berbagai informasi.

3. Media sosial memberikan kesempatan untukberinteraksi lebih dekat dengan konsumen. Mediasosial memberikan suatu bentuk komunikasi yanglebih individual, personal dan dua arah. Melalui media sosial para pemasar dapat mengetahui kebiasaan konsumen mereka dan melakukan interaksi secara personal serta membangun keterikatan yang lebih dalam.

4. Media sosial memiliki sifat viral. Viral berartimemiliki sifat seperti virus yaitu menyebardengan cepat. Informasi yang muncul dari suatu produk dapat tersebar dengan cepat karena para penghuni sosial media memiliki karakter berbagi.

\section{B. Netizen}

Netizen disebut juga sebagai warganet,merupakan singkatan dari warga internet atau yang sering disebut pengguna media sosial, (kbbi.kemdikbud.go.id) [6].

Istilah netizen dibentuk dari dua kata: internet dan citizen (warga). jadi, bisa disimpulkan, netizen adalah user (pengguna) internet aktif dalam berkomunikasi, mengeluarkan pendapat, berkolaborasi, di media internet, Gamayanto (2017) [7]

\section{Etika Bermedia Sosial}

Etika bermedia sosial merupakan suatu norma atau aturan yang dipakai sebagai pedoman berekspresi dalam berinteraksi di media sosial, Nugroho dalam Muanas 2020. [8]

Selanjutnya dalam menggunakan media sosial ada beberapa etika yang harus digunakan. 5 etika bersosial media, (batikominfo.id) [9] diantaranya:

\section{Penggunaan Bahasa}

Dalam beraktivitas di media sosial, hendaknya selalu menggunakan bahasa yang baik dan benar sehingga tidak menimbulkan resiko kesalahpahaman yang tinggi. Dengan mengirimkan konten berbahasa yang baik dan benar pun resiko salah paham masih mungkin terjadi, terlebih jika bahasa yang digunakan tidak benar. Jika menuliskan sesuatu, upayakan menuliskannya secara jelas agar setidaknya ketika ada orang lain yang membaca tulisan tersebut dapat memahami apa yang ingin disampaikan. Hindari penggunaan kata atau frasa multitafsir jika tidak dimaksudkan demikian, serta gunakan setiap kata sesuai dengan peruntukannya. Sederhana, setiap orang memiliki preferensi yang berbeda, dan dapat memaknai konten secara berbeda, setidaknya dengan menggunakan bahasa yang jelas dan lugas Anda telah berupaya mengunggah konten yang jelas pula.

DOI: $10.52362 /$ jisicom.v5i1.465

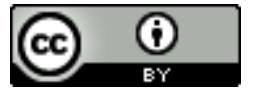

Ciptaan disebarluaskan di bawah Lisensi Creative Commons Atribusi 4.0 Internasional. 


\section{Menghargai Orang Lain}

Sikap menghargai orang lain tidak hanya ideal jika ditunjukkan pada saat berkomunikasi secara langsung, namun juga pada media sosial. Menghargai di sini lebih pada konteks tidak mencela atau menghina, namun lebih kepada membuat interaksi yang hangat dengan diskusi informatif dan tidak sekedar berdasarkan dengan pendapat. Dalam konteks media sosial, mungkin untuk menghargai orang lain kita dituntut untuk membaca sebelum berkomentar. Membaca, melihat apa konteks konten yang disampaikan, bagaimana latar belakang si pengunggah konten dan sebagainya. Dengan sedikit kebijaksanaan ini idealnya interaksi di media sosial akan terjadi dengan lebih produktif dan tidak bersifat negatif.

3. Kontrol pada Konten

Unggahan yang Anda lakukan, wajarnya, dapat dilihat oleh banyak orang. Sangat tidak disarankan untuk mengunggah apapun yang bersifat informasi pribadi, seperti misalnya nomor kartu debit atau kredit, NIK, nomor telepon, alamat rumah dan berbagai hal personal lain. Hal ini untuk meminimalisir kejadian tidak diinginkan dan menjaga keamanan Anda dan orang terdekat. Pada dasarnya, setiap pemilik akun media sosial memiliki kontrol pada konten yang mereka unggah atau dapat mereka lihat. Hal ini yang jarang dipahami banyak orang, sehingga menimbulkan berbagai permasalahan. Padahal jika setiap orang mau melakukan filtrasi pada konten yang diunggah atau disaksikannya, pasti iklim media sosial di Indonesia akan lebih sejuk.

4. Overposting

Memang menjadi hak setiap pemilik akun media sosial untuk pengunggahan konten pada akunnya. Namun bayangkan jika setiap hari Anda harus sarapan dengan menu yang sama, tidakkah Anda bosan? Hal yang sama juga berlaku pada unggahan yang Anda lakukan. Sebisa mungkin, kontrol jumlah unggahan yang Anda lakukan sehingga tidak menjadi overposting. Overposting berarti melakukan unggahan yang terlalu banyak sehingga dapat bersifat mengganggu daripada informatif. Memang, sekali lagi kontrol pada konten dapat dilakukan, namun jika bisa dimulai dari diri sendiri, hal ini tentu akan jauh lebih ideal yang menyenangkan untuk orang banyak. Meskipun jumlah 'terlalu banyak' juga sangat relatif, setidaknya Anda pasti mengetahui ketika Anda sudah mengunggah terlalu banyak konten pada satu waktu tertentu.

\section{Preferensi bukan Plagiasi}

Memiliki identitas dan karakter yang kuat dalam bermedia sosial juga sangat penting dan menjadi satu variabel dalam etika bersocial media. Setiap pemilik akun tentu memiliki 'pasar'nya masing-masing, sehingga akan sangat tidak etis jika Anda melakukan plagiasi, baik dari segi nama ataupun jenis konten yang Anda unggah karena dapat membuat pemilik akun lain tidak nyaman. Memiliki preferensi konten yang luas memang penting, namun hal ini idealnya hanya menjadi acuan saja dan bukan menjadi 'kiblat' utama. Secara ideal setiap manusia memiliki keunikan masing-masing, dan keunikan ini yang akan menciptakan pasar untuk konten yang Anda unggah.

\section{Undang - Undang ITE 2008}

UU ITE Nomor 11 tahun 2008 merupakan salah satu Undang-Undang yang mengatur tentang informasi serta transaksi elektronik, atau teknologi informasi secara umum. Undang-Undang ITE memiliki suatu aturan yuridiksi yang berlaku untuk setiap orang yang melakukan perbuatan hukum sebagaimana diatur dalam Undang-Undang ini, baik yang beradadi wilayah hukum Indonesia maupun di luar wilayah hukum Indonesia, yang mana memiliki suatu akibat hukum di wilayah hukum Indonesia dan atau di luar wilayah hukum Indonesia dan merugikan kepentingan Indonesia. Dalam Undang-UndangInformasi dan Transaksi Elektronik (UU ITE), materi dibagi menjadi dua bagian besar, yaitu pengaturan mengenai informasi dan transaksi elektronik dan pengaturan mengenai perbuatan yang dilarang (Bersosmed, 2017) [3].

DOI: $10.52362 /$ jisicom.v5i1.465

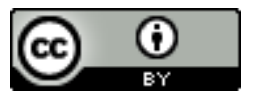

Ciptaan disebarluaskan di bawah Lisensi Creative Commons Atribusi 4.0 Internasional. 
UU ITE Pasal 28 Ayat 2, berbunyi "setiap orang dilarang dengan sengaja dan tanpa hak menyebarkan informasi yang ditujukan untuk menimbulkan rasa kebencian atau permusuhan individu dan/atau kelompok masyarakat tertentu berdasarkan atas suku, agama, ras, dan antar golongan (SARA), (www.dpr.go.id) [10]

\section{E. Virtual Police}

Virtual Police adalah upaya Korps Bhayangkara untuk memberikan edukasi kepada publik agar tidak menyebarkan konten yang diduga melanggar hukum, Argo Yuwono 2021 (tirto.id) [11]. Virtual police untuk memberikan edukasi kepada masyarakat demi menciptakan ruang siber yang damai dan sehat, Sigit 2021 (nasional.kompas.com) [12]

Selanjutnya menurut Novi, polisi virtual adalah upaya Polri memoderasi konten negatif di dunia maya terutama yang mengarah pada pelanggaran pidana, 2021 (www.liputan6.com) [13]

Pelaksanaan tugas virtual police merujuk pada Surat Edaran (SE) Kapolri bernomor SE/2/11/2021 Tentang Kesadaran Budaya Beretika Untuk Mewujudkan Ruang Digital Indonesia yang Bersih, Sehat dan Produktif. Upaya tersebut bertujuan untuk memonitor, mengedukasi, memberikan peringatan, serta mencegah masyarakat dari potensi tindak pidana siber. Dalam melaksanakan tugasnya Virtual police melayangkan peringatan kepada akun-akun media sosial yang mengunggah konten dengan unsur SARA, Sigit 2021 (nasional.kompas.com) [12]

\section{METODOLOGI PENELITIAN}

Adapun metode penelitian yang digunakan dalam penelitian ini adalah metode penelitian semi deskriptif kuantitatif yaitu penelitian yang bertujuan menjelaskan fenomena yang ada denganmenggunakan angka-angka untuk mendeskripsikan karakteristik individu atau kelompok.

\section{HASIL DAN PEMBAHASAN}

Media sosial yang pada awalnya digunakan untuk media berbagi berbagai hal yang positif dan sering digunakan sebagai media untuk bersilahturahmi sangat memberikan manfaat yang positif bagi masyrakat pengguna media sosial di Indonesia, dimana hingga saat ini pengguna media sosial di Indonesia sudah mencapai 170 juta pengguna dan rata-rata dari mereka menghabiskan waktu 3 jam 14 menit di platform jejaring sosial, (We Are social \& Hootsuite, 2021).

Media sosial menjadi hal yang menarik bagi masyrakat pengguna internet karna media sosial dapat menghubungkan seluruh elemen masyrakat dimanapun berada dan media sosial menjadi trend gaya hidup masyrakat Indonesia yang tidak bisa dipisahkan dari bagian keseharian masyrakat, We Are social \& Hootsuite, 2021 menyatakan masyarakat pengguna media sosial di Indonesia rata-rata menghabiskan waktu mereka 3 jam 14 menit di platform jejaring sosial. Dan media sosial yang paling banyak digunakan adalah YouTube, WhatsApp, Instagram, Facebook dan Twitter.

Dengan waktu yang panjang tersebut banyak masyrakat yang memanfaatkan media sosial untuk ajang pertemanan, membuktikan eksistensi diri dengan mengupdate status, berbagi foto maupun video dan membuat konten-konten kreatif yang bisa memberikan dampak positif bagi pengguna media sosial lainnya dan banyak pengguna media sosial yang memanfaatkan media sosial untuk mendulang rupiah melalui konten-konten yang dibagikan melalui jejaring sosial, sperti youber dan pengguna media sosial juga menggunakan facebook maupun istagram dan media sosial lainnya sebagai media promosi dalam berbisnis online.

Namun dari banyaknya manfaat media sosial tersebut tidak semua netizen memanfaatkannya dengna baik, banyak pengguna media soial atau netizen yang menggunakan media sosial untuk hal-hal yang negatif, menggunakan media sosial tanpa menggunakan etika yang baik sehingga berpotensi menimbulkan kegaduhan dimedia sosial dengan cara mengunggah sebuah status, foto atau video maupun melalui komentar-komentar yang berisi ujaran kebencian (hate speech). Adanya ujuran kebencian tersebut otomatis akan menimbulkan berbagai DOI: $10.52362 /$ jisicom.v5i1.465

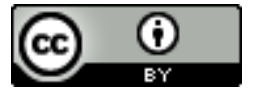

Ciptaan disebarluaskan di bawah Lisensi Creative Commons Atribusi 4.0 Internasional. 
reaksi dimasyrakat yang bisa menimbulkan kegaduhan sehingga bisa memicu terjadinya konflik internal maupun konflik sosial.

Pengguna media sosial yang melakukan ujaran kebencian dimedia sosial datang dari beragam latar belakang masyrakat mulai dari masyrakat biasa hingga publik pigur, sebagai contoh yang menjadi perhatian publik diantaranya kasus ujaran kebencian yang dilakukan Ahmad Dhani, melalui ungahannya di Twitter @AHMADDHANIPRAST pada tahun 2017, yang menimbulkan kegaduhan di media sosial karna melalui unggahan tersebut menimbulkan berbagai opini maysrakat, unggahan tersebut dianggap mendiskreditkan orang lain yang berisi muatan kebencian dan dianggap telah melanggar UU ITE Tahun 2008 Pasal 28 ayat 2 sehingga Ahmad Dhani dijatuhi hukuman 1.6 tahun penjara, 2019 (m.tribunnews.com) [14]

Hal yang sama juga dilakukan Jerinx SID melalui akun Istagram miliknya @jrxsid yang menyatakan "IDI Kacung WHO" pernyataan tersebut dianggap memenuhi unsur UU ITE Pasal 28 ayat 2, berisi muatan ujaran kebencian sehingga Jerinx SID dilaporkan IDI (Ikatan Dokter Indonesia) yang menyebabkan Jerinx SID dijatuhi hukuman penjara selama 1 tahun 2 bulan, (www.cnnindonesia.com) [15] dan kemudian Jerinx SID melakukan banding hingga dijatuhi hukam 10 bulan penjara, 2021 (nasional.tempo.co) [16]

Keberadaan UU ITE Tahun 2008 pasal 28 ayat 2 belum juga mampu secara signifikan dalam mengurangi ujaran kebencian, meskipun para pengguna media sosial yang melakukan ujian kebencian akan menerima hukuman akan tetapi pada kenyataanya hal tersebut belum memberikan memberikan efek jera secara maksimal pada pengguna media sosial yang menyebarkan ujaran kebencian, Polda Metro Jaya, pada tanggal 23 Desember 2020, Kapolda Irjen Fadil Imran menyatakan dalam kurun waktu 2020 Polda Metro Jaya telah menangani 443 kasus kejahatan cyber dan mentake down 1.448 akun media sosial dan diantara kasus-kasus tersebut, hate speech dan hoax masih masih tetap mendominasi, meskipun pun secara jumlah penanganan kasus kejahatan cyber telah berkurang pada tahun 2020 sebanyak 5 persen dibanding pada tahun 2019. (news.detik.com). [17]

Divisi Humas POLRI, Ahmad Ramadhan menyampaikan diawal semester pertama tahun 2021, dalam Periode 23 Februari sampai 11 Maret 2021, terdapat 125 konten yang diberikan peringatan melalui Virtual Police, 89 diantaranya mengandung ujaran kebencian, dengan menggunakan plafform Twitter 79 konten, Facebook 32 konten, Istagram 8 konten, Youtube 5 konten dan Whatsapp 1 konten, (nasional.okezone.com) [18]

Direktorat Tindak Pidana Siber (Dittipidsiber) Bareskrim Polri Brigjen Slamet Uliandi dalam keterangannya, Sabtu 08 Mei 202, menyatakan Virtual Police telah memberikan peringatan atau teguran (VP) kepada 419 akun media sosial yang dinilai melakukan pelanggaran UU ITE. Teguran tersebut disampaikan dimulai sejak tanggal 23 Februari sampai 3 Mei 2021. Dari 419 teguran, 274 diantaranya dinyatakan lolos verifikasi atau konten yang diajukan memenuhi unsur ujaran kebencian berdasarkan SARA dan media sosial yang paling banyak diberikan teguran virtual police adalah twitter 215 akun, facebook 180 akun, istagram 14 akun dan yang terakhir youtube 9 akun, 2021 (www.tribunnews.com) [19]

Dan dalam rangka mengurangi ujaran kebencian dimedia sosial pemerintah berupaya melakukan berbagai upaya diantaranya melalui Virtual Police yang digagas oleh KAPOLRI Jend Listyo Sigit Prabowo yang bertujuan untuk memonitor, mengedukasi, memberikan peringatan serta mencegah masyrakat dari potensi tindak pidana siber, 2021 (nasional.kompas.com) [12]

Selanjutnya Menteri Komunikasi dan Informatika Johnny G. Plate Dan pada 16 April 2021, meluncurkan empat modul literasi digital di Ballroom Grand City Surabaya, Jawa Timur,. Empat modul literasi itu meliputi Budaya Bermedia Digital, Aman Bermedia Digital, Etis Bermedia Digital dan Cakap Bermedia Digital, 2021 (nasional.tempo.com) [20]

Adanya wacana dari pemerintah untuk merevisi UU ITE 2008, yang digaungkankan Presiden Jokowi bertujuan menjaga ruang digital Indonesia agar bersih, sehat, beretika, penuh sopan santun, penuh tata karma dan produktif, 2021 (m.antaranews.com) [21]. Revisi UU ITE demi menjaga ruang digital tetap bersih dan beretika dan tetap menjaga kebabasan berpendapat, 2021 (www.liputan6.com) [22]

DOI: $10.52362 /$ jisicom.v5i1.465

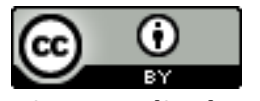

Ciptaan disebarluaskan di bawah Lisensi Creative Commons Atribusi 4.0 Internasional. 
e-ISSN : 2597-3673 (Online), p-ISSN : 2579-5201 (Printed)

Journal of Information System, Informatics and Computing

Vol.5 No.1, Juni 2021

Website/URL: http://journal.stmikjayakarta.ac.id/index.php/jisicom

Email: jisicom@stmikjayakarta.ac.id, jisicom2017@gmail.com

Berbagai upaya diatas diharapkan mampu menjadikan media sosial Indonesia bisa menjadi ruang digital yang menyenangkan, adanya UU ITE 2008 pasal 28 ayat 2 bisa dipahami dengan baik oleh masyrakat pengguna media sosial sehingga ujaran kebencian tidak ditemukan lagi dimedia sosial, para pengguna media sosial menggunakan media sosial dengan etika yang baik dan dimanfaatkan secara produktif untuk kebaikan hidup.

\section{KESIMPULAN}

Media sosial yang menjadi bagian dari trend gaya hidup masyrakat Indonesia memberikan banyak manfaat dimana masyrakat menggunakan media sosial untuk berbagai hal, mulai dari wadah pertemanan, sebagai ruang untuk mengekpresikan diri termasuk media untuk berbisnis online dan mendulang rupiah melalui konten-konten kreatif sperti youtuber. Adanya UU ITE Tahun 2008 UU ITE 2008 Pasal 28 ayat 2 yang dianggap sebagai hulu dalam bermedia sosial kiranya mampu mengurangi ujaran kebencian dimedia sosial terlebih saat ini di Indonesia ada Virtual Police untuk memantau pengguna media sosial untuk mengurangi pidana siber sehingga ujaran kebencian dimedia sosial bisa diminimalisir atau dikurangi sehingga tercipta ruang digital yang menyenangkan dan beretika, memberikan pengalaman yang menarik buat penggunanya, media sosial digunakan untuk secara cerdas dan bijaksana untuk membaikkan kehidupan.

DOI: $10.52362 /$ jisicom.v5i1.465

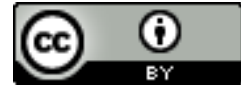

Ciptaan disebarluaskan di bawah Lisensi Creative Commons Atribusi 4.0 Internasional. 
e-ISSN : 2597-3673 (Online), p-ISSN : 2579-5201 (Printed)

Vol.5 No.1, Juni 2021

Journal of Information System, Informatics and Computing

Website/URL: http://journal.stmikjayakarta.ac.id/index.php/jisicom

Email: jisicom@stmikjayakarta.ac.id , jisicom2017@gmail.com

\section{REFERENASI}

[1] We Are social \& Hootsuite (2021). https://tekno.kompas.com/read/2021/02/23/16100057/jumlah-pengguna-internetindonesia-2021-tembus-202-juta

[2] Okky dan Budi, (2020). https://tekno.tempo.co/read/1410572/peneliti-ui-deteksi-ujaran-kebencian-di-twitter-pakaiai/full\&view $=$ ok

[3] Bersosmed, G. B. (2017). Bijak Bersosmed Tips danInformasi Gerakan \#BijakBersosmed 2017. Jakarta

[4] Nasrullah, Rulli. 2015. Media Sosial; Persfektif Komunikasi, Budaya, dan Sosioteknologi. Bandung : Simbiosa Rekatama Media

[5] Puntoadi, D. (2011). Menciptakan Penjualan melalui Social Media. Jakarta: PT. Elex Media Komputindo.

[6] Netizen, https://kbbi.kemdikbud.go.id/entri/netizen

[7] Gamayanto, 2017. Pengembangan dan Implementasi dari Wise Netizen (EComment) di Indonesia, Jurnal Techno.COM, Vol. 16, No. 1, 80-95

[8] Muannas, 2020. Model Literasi Digital untuk Melawan Ujaran Kebencian di Media Sosial. Jurnal IPTEK-KOM (Jurnal Ilmu Pengetahuan dan Teknologi Komunikasi) Vol. 22 No. 2, 125 - 142

[9] Etika Bersosial Media,

https://www.baktikominfo.id/id/informasi/pengetahuan/5_etika_bersocial_media_pahami_dan_terapkan_setiap_poin nya-1053

[10] UU ITE www.dpr.go.id

[11] https://tirto.id/apa-itu-virtual-police-aturan-cara-kerja-dan-kaitan-dengan-uu-ite-gaBQ

[12] KAPOLRI, Jend Listyo Sigit, (2021). https://nasional.kompas.com/read/2021/03/17/14414171/mengenal-virtualpolice-definisi-dasar-hukum-hingga-polemiknya

[13] Novi (2021). https://www.liputan6.com/regional/read/4494264/polisi-virtual-awasi-konten-medsos-ini-kata-pakarliterasi-digital-ugm

[14] Ahmad Dhani, (2019). https://www.tribunnews.com/nasional/2019/01/28/3-kicauan-ahmad-dhani-di-twitter-yangmembuatnya-divonis-1.5-tahun-penjara-karena-ujaran-kebencian

[15] Jerinx, (2020). https://www.cnnindonesia.com/nasional/20201119092502-12-571726/jerinx-divonis-1-tahun-2bulan-penjara-kasus-idi-kacung-who\#

[16] Jerinx, (2021). https://www.nasional.tempo.co/amp/1424686/kasus-ujaran-kebencian-jerinx-sid-menerimaputusan-banding-10-bulan-penjara

[17] Irjen Fadil Imran, (2020). https://news.detik.com/berita/d-5308010/polda-metro-tangani-443-kasus-cyber-selama2020-1448-akun-di-take-down

[18] Ahmad Ramadhan (2021). https://www.nasional.okezone.com/amp/2021/03/12/337/2376693/polri-sebut-89-akunmedsos-sebarkan-ujaran-kebencian-paling-banyak-di-twitter

[19] Slamet Uliandi, (2021). https://www.tribunnews.com/nasional/2021/05/09/419-akun-medsos-ditegur-virtualpolice-paling-banyak-di-twitter

[20] Menkominfo (2021). https://nasional.tempo.co/read/1453376/luncurkan-4-modul-literasi-digital-kominfo-ingintangkal-sebaran-konten-negatif

[21] Presiden Jokowi (2021). https://m.antaranews.com/berita/2042742/revisi-uu-ite-dan-upaya-menjaga-ruang-digitaltetap-beretika

[22] Presiden Jokowi (2021) https://www.liputan6.com/news/read/4484375/headline-jokowi-usulkan-dpr-revisi-uu-itedan-hapus-pasal-karet-angin-segar-demokrasi

DOI: $10.52362 /$ jisicom.v5i1.465

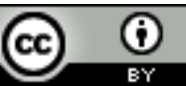

Ciptaan disebarluaskan di bawah Lisensi Creative Commons Atribusi 4.0 Internasional. 